\title{
Current situation and future prospects for beef production in Lao People's Democratic Republic - A review
}

\author{
Pattaya Napasirth ${ }^{1, a, *}$, and Viengsakoun Napasirth ${ }^{2, a, *}$
}

\author{
* Corresponding Authors: \\ Pattaya Napasirth \\ Tel: +66-62-609-8666, Fax: +66-42241418, \\ E-mail: pattaya_napasirth@hotmail.com \\ Viengsakoun Napasirth \\ Tel: +856-20-2224-0334, Fax: +856-21870131 \\ E-mail: v.napasirth@nuol.edu.la
}

' Program in Animal Production Technology, Faculty of Technology, Udon Thani Rajabhat University, Udon Thani, 41000, Thailand

2 Department of Livestock and Fisheries, Faculty of Agriculture, National University of Laos, Vientiane Capital, 856, Lao People's Democratic Republic

a These authors contributed equally to this work.

ORCID

Pattaya Napasirth

https://orcid.org/0000-0001-8506-7965

Viengsakoun Napasirth

https://orcid.org/0000-0001-5622-4896

Submitted Mar 15, 2018; Revised Apr 2, 2018; Accepted May 1, 2018

\begin{abstract}
Lao-native beef cattle are primarily Bos indicus, and most ruminant production in Laos is still dominated by small-scale or backyard producers that use traditional practices, resulting in low productivity. The cattle herd size in Laos has grown by an average of 5 percent per year from 1.52 million in 2010/11 to 1.81 million in 2014/15. In 2016, the Laos cattle population was 1.88 million head, with smallholder farmers representing $98 \%$ of production despite efforts by the Laos government to develop commercial-scale farms. There were 170 commercial cattle farms in 2016, with 56 percent in the Central region of Laos. Although, overall, ruminant meat production has tended to increase but with consumption at $7.29 \mathrm{~kg} / \mathrm{capita} / \mathrm{yr}$ in 2013, it remains insufficient to meet demand. Crop residues and agro-industrial by-products used in ruminant diets include rice straw, cassava pulp and wet brewers' grains as roughage, energy and protein sources, respectively. The Belt and Road Initiative proposed by China in 2013 will connect China closely with all countries in Southeast Asia. This initiative will change landlocked Laos to land linked for investors who will benefit from convenient transport at a lower cost, promoting agricultural production in Laos.
\end{abstract}

Keywords: Beef Cattle; Smallholder Farmers; Laos Cattle; Lao PDR

\section{INTRODUCTION}

The Lao People's Democratic Republic (Lao PDR, or Laos) is a landlocked nation with an area of 236,800 $\mathrm{km}^{2}$ located in the heart of the Greater Mekong Subregion (GMS), Laos shares borders with five countries: People's Republic of China and Myanmar in the Northwest, Cambodia in the South, Vietnam in the East, and Thailand in the West. Laos has the lowest human population of the region, with 6.4 million people (27 people per square kilometer), and around $67 \%$ of the population lives in rural areas [1] and are dependent on agrarian activities for their livelihoods. Most livestock, including buffalo, beef cattle, poultry and swine, are produced by villagers using traditional practices, resulting in low productivity. The Lao-native beef cattle are primarily Bos indicus [2]. The coat colors of these cattle are mainly yellow to brown and black, however various other coat colors are also observed.

This paper presents an overview of the Laos beef sector, including a review of the current situation and changes over recent decades on the Laos beef cattle industry including beef production, consumption, recent trends, and future prospects.

\section{CURRENT SITUATION FOR BEEF PRODUCTION IN LAOS}

\section{Regional distribution of beef cattle in Laos}

Smallholder livestock owners in Laos traditionally keep cattle as a means of storing wealth, a source of income, for meat consumption, livelihoods, to provide draught power for trans- 
port, traditional culture, and provision of manure as fertilizer for cropping. Ruminant production in Laos is still dominated by small-scale or backyard producers using traditional techniques with mostly indigenous breeds usually kept under free range situations; ruminants graze on natural pastures, on the roadside, on fallow land, in paddy fields after the harvest, and in the forest, hence natural pastures represent the main source of ruminant feed in Laos. FAOSTAT [3] reported the total arable land of Laos is about 1.52 million ha and permanent meadows and pastures approximately 0.67 million ha in 2014 . Moreover, the quality and quantity of the natural forages found in Laos depend on the plant species and season $[4,5]$. There is a general decline in crude protein content in most common forage crops from the rainy season to the dry season. Although the rainy season produces high quantity and quality forage, feed resources are inadequate because ruminants are not allowed to venture onto the wetlands or the rice paddy fields during the rainy season. As rice growing occupies an important proportion of arable land in Laos, farmers tend to restrict the number of cattle they raise to avoid excessive damage to rice paddy fields for which the owner is held responsible. This controls ruminant nutrition to feed accessible on the roadside, levy banks and other non-cultivated areas.

Currently, livestock is one of the fastest growing agricultural subsectors in Laos. It was reported that cattle herd sizes have grown by an average 5 percent per year, from 1.52 million in FY2010-2011 to 1.81 million in FY2014-2015 [1], with this growth is motivated by rapidly increasing requirements for livestock products by 3.5 to 4.0 percent annually, leading to expanded livestock production in Laos [6]. This demand is being driven by increased incomes and urbanization. Laos had around 1.15 million of cattle in 2000 with an annual growth rate of $2.16 \%$ in the period 2000 through 2014 [3]. In 2016, the Laos cattle population was about 1.88 million head, with smallholder farmers having approximately $98 \%$ of cattle in Laos. This is despite efforts by the Laos government to develop commercial-scale farms, of which there was 170 commercial cattle farms in 2016. About 56 percent of the cattle in Laos are in the Central region, 26 percent in the Northern region, and 17 percent in the Southern region (Table 1) [6].

\section{Beef consumption in Laos}

FAOSTAT [3] reported that during 2013, pork consumption was estimated at $9.31 \mathrm{~kg} / \mathrm{capita}$, followed by bovine meat at $7.29 \mathrm{~kg} / \mathrm{capita}$ and poultry meat $4.21 \mathrm{~kg} / \mathrm{capita}$. The resultant trends in meat consumption in Laos is shown in Figure 1. Laos domestic beef consumption has increased greatly since 1988 although the average price of buffalo and bovine meat have increased more than double from 4.09 US\$ per kilogram in 2009 to 8.05 US\$ per kilogram in 2016 [7-11] (Table 2) with a gross national income per capita of \$2,150 in 2016 [12]. Per capita beef consumption rose from $6.12 \mathrm{~kg} / \mathrm{yr}$ in 2000 to 7.29 $\mathrm{kg} / \mathrm{yr}$ in 2013. Compared with other regional countries, meat consumption per capita in Laos was higher than in Thailand

Table 1. Cattle production in Laos in 2016 (Unit: Head) [6]

\begin{tabular}{|c|c|c|c|c|c|}
\hline \multirow{2}{*}{ Provinces } & \multirow{2}{*}{ Cattle population } & \multicolumn{2}{|c|}{ Commercial farms } & \multicolumn{2}{|c|}{ Beef cattle farmers groups } \\
\hline & & No. of farms & Animals & No. of groups & Animals \\
\hline Northern region & 490,256 & 50 & 4,198 & 116 & 7,518 \\
\hline Phongsaly & 52,016 & 1 & 140 & - & - \\
\hline Luangnamtha & 24,901 & - & - & 10 & 4,296 \\
\hline Oudomxay & 42,657 & 12 & 600 & 2 & 6 \\
\hline Bokeo & 59,893 & 16 & 1,203 & - & - \\
\hline Luangprabang & 89,834 & 8 & 795 & 80 & 1,869 \\
\hline Houaphanh & 89,669 & - & - & 16 & 683 \\
\hline Sayaboury & 131,286 & 13 & 1,460 & 8 & 664 \\
\hline Central region & $1,053,867$ & 64 & 8,196 & 255 & 9,725 \\
\hline Vientiane Capital & 77,263 & 21 & 2,077 & 12 & 578 \\
\hline Xiangkhouang & 136,915 & 10 & 956 & 69 & 1,596 \\
\hline Xaysomboun & 41,376 & - & - & - & - \\
\hline Vientiane & 173,401 & 8 & 2,754 & 1 & 1,241 \\
\hline Borikhamxay & 65,133 & 7 & 608 & 173 & 6,310 \\
\hline Khammuane & 118,051 & 9 & 517 & - & - \\
\hline Savannakhet & 441,728 & 9 & 1,284 & - & - \\
\hline Southern region & 337,783 & 56 & 16,447 & 0 & 0 \\
\hline Saravan & 115,485 & 22 & 732 & - & - \\
\hline Sekong & 27,079 & 5 & 4,235 & - & - \\
\hline Champasack & 167,216 & 21 & 9,850 & - & - \\
\hline Attapeu & 28,003 & 8 & 1,630 & - & - \\
\hline Total & $1,881,906$ & 170 & 28,841 & - & - \\
\hline
\end{tabular}




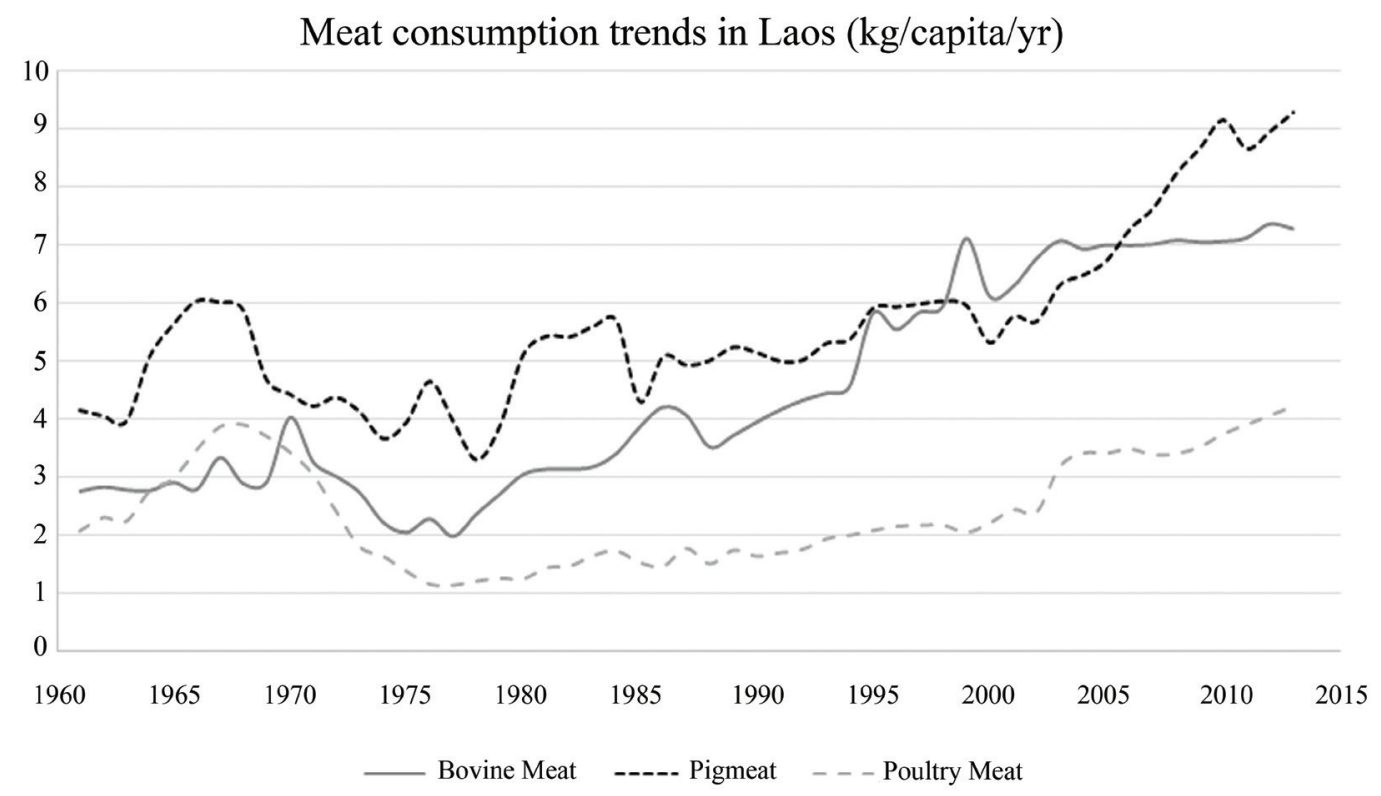

Figure 1. Meat consumption trends in Laos [3].

$(2.56 \mathrm{~kg} / \mathrm{yr})$ and on par with that of Vietnam [3]. The growth in cattle production is mainly to meet increasing domestic demand. Recently, there has been a trend towards higher quality food and food diversity, mainly because of the growing economy and the open market systems. Although, beef consumption in Laos is almost $100 \%$ of the total meat production of the country, high quality beef needs to be imported for restaurants and supermarkets in Vientiane, the Laos capital.

The Laos government's objective is to improve beef production by increasing the live weight of the Lao-native cattle and by introducing exotic breeds. Recently, Wagyu cattle farm- ing in Laos has been established with the aim of providing high quality meat. Whilst the supply of bovine meat can fulfill domestic needs, the country relies on imports to provide breeding animals to household producers. In addition, export of livestock products from Laos is very limited and the export value of meat is low (Table 3 ) and has fluctuated over the years [6].

\section{Beef production in Laos}

Ruminant production in Laos is still dominated by small-scale or backyard producers. Growth performance of ruminants is

Table 2. Animal populations and prices of meat products in Laos

\begin{tabular}{|c|c|c|c|c|c|c|c|c|c|c|}
\hline \multirow{2}{*}{ Year } & \multirow{2}{*}{ GNI } & \multicolumn{2}{|c|}{ Buffalo } & \multicolumn{2}{|c|}{ Cattle } & \multicolumn{2}{|c|}{ Broiler } & \multicolumn{2}{|l|}{ Pig } & \multirow{2}{*}{ References } \\
\hline & & $\times 1,000$ head & USD/kg & $\times 1,000$ head & USD $/ \mathrm{kg}$ & $\times 1,000$ head & USD/kg & $\times 1,000$ head & USD/kg & \\
\hline 2009 & 890 & 1,178 & 3.9 & 1,430 & 4.1 & 22,521 & 4.1 & 2,555 & 3.6 & [7] \\
\hline 2010 & 1,000 & 1,183 & 3.9 & 1,474 & 4.1 & 24,079 & 4.1 & 2,753 & 3.8 & [7] \\
\hline 2011 & 1,120 & 1,197 & 4.5 & 1,538 & 4.6 & 26,852 & 3.8 & 2,650 & 4.2 & [8] \\
\hline 2012 & 1,350 & 1,188 & 5.4 & 1,692 & 5.5 & 28,779 & 3.8 & 2,794 & 4.4 & [9] \\
\hline 2013 & 1,590 & 1,190 & - & 1,714 & - & 30,727 & - & 2,948 & - & [10] \\
\hline 2014 & 1,840 & 1,153 & 7.9 & 1,766 & 7.9 & 32,408 & 4.3 & 3,122 & 4.9 & [10] \\
\hline 2015 & 2,000 & 1,165 & - & 1,828 & - & 34,422 & - & 3,258 & - & [11] \\
\hline 2016 & 2,150 & 1,177 & 8.0 & 1,923 & 8.1 & 35,150 & 4.0 & 3,700 & 4.7 & [11] \\
\hline
\end{tabular}

GNI, gross national income per capita (USD).

Table 3. Laos beef cattle numbers, slaughter for consumption, and import and export (head) in 2016 [6]

\begin{tabular}{lccccc}
\hline Item & Total cattle & Total slaughter & Import for slaughter & Import for breeding & Export \\
\hline Northern region & 490,256 & 18,581 & - & 5 & - \\
Central region & $1,053,867$ & 70,799 & 6,515 & 606 & 992 \\
Southern region & 337,783 & 51,501 & - & 112 & - \\
Total & $1,881,906$ & 140,881 & 6,515 & 723 & 992 \\
\hline
\end{tabular}


principally limited by natural forage quantity and quality in Laos because the ruminant grazed freely on roadsides, grassland, and the paddy field after harvesting during the day and return home later in the day to the nearby villages. Our preliminary work on the quality and chemical composition of natural pasture in Laos (Table 4) has demonstrated that most local grass species have low nutritive value, resulting in low voluntary feed intake and nutrient digestibility. High quality forage plantations have been encouraged to manage feed shortages and deliver a resource for fattening of ruminants before sale to increase their value. Several species of grass, including Napier grass (Pennisetum purpureum), Ruzi grass (Brachiaria ruziziensis), Mulato grass (Brachiaria sp.), Guinea grass (Panicum sp.), Signal grass (Brachiaria decumbens), Atratum grass (Paspalum atratum), and other high quality grasses have been imported into Laos to complement existing natural feeds. Moreover, farmers in Laos have been trained in silage production using high quality grasses but silage has not yet been implemented in many farms. Usually, farmers offer rice straw as the main roughage source to their animals. Therefore, large numbers of ruminants suffer from serious feed shortages both in quality and quantity.

Alternative local feed sources for ruminants: At present, there are 15 food processing factories with investment value of more than 50 billion Kip (6 million US\$), including a maize drying and jatropha extraction factory, Beer Lao Ltd, Lao Asia-Pacific Brewery Ltd, Lao-Indochina Group Co., Ltd tapioca factory, a cassava processing factory in Sayaboury province, factory potatoes TTL in Bolikhamxay province, Dak Tak Rubber Fac- tory and Lao-Vietnam Rubber Factory, Dao Heuang Coffee, sugar and cement factories [1]. Crop residues along with agroindustrial by-products are important in the feeding of ruminant animals under different systems. However, the value of cropresidues or agro-industrial by-products from in a particular area depends on the amount and type of crops grown in each area. Based on a review of the literature, the most common crop residues and agro-industrial by-products used in ruminant diets are rice straw, cassava pulp and wet brewers' grains as roughage, energy and protein sources, respectively.

Laos had a total paddy rice area of 957,836 ha [3], hence rice straw is the most abundant feed resource for ruminants (Table 5). Rice straw is low in protein, so cannot support adequate microbial growth and/or meet the nutrient requirement for increased performance of ruminants. Ways for enhancing the feed value of crop-residues include the treatment of rice straw with urea or alkaline chemicals such as lime [17-19], although most of these techniques have not been adopted in the traditional smallholder sector. Even though chemical treatment has showed positive effects for voluntary feed intake and nutrient digestibility of rice straw, its applicability in rural areas is restricted due to the cost and availability of these chemicals. Importantly, after harvest the majority of rice straw are considered as a problem and are often burnt to clear the fields for the next cropping season.

Cassava farms are needed not only for a major source of income for rural households but also for use in ruminant diets. During the period 2005 trough 2012 there were 12 private domestic and 11 foreign companies registered to manage cassava

Table 4. Natural pasture and their typical nutritive value for ruminants in Laos

\begin{tabular}{|c|c|c|c|c|c|}
\hline \multirow{2}{*}{ Local name } & \multirow{2}{*}{ Scientific name } & \multicolumn{3}{|c|}{ Chemical composition (\%) } & \multirow{2}{*}{ References } \\
\hline & & DM & $\mathrm{CP}$ & NDF & \\
\hline Elephant grass & Pennisetum purpureum & 29.0 & 6.1 & 73.1 & {$[13]$} \\
\hline Kham grass & Thysanolaena latifolia & 26.4 & 10.6 & 69.1 & \\
\hline Guatemala grass & Tripsacum laxum & 16.1 & 7.8 & 59.0 & \\
\hline Pakhuay grass & Dactyloctenium aegyptium (L.) P.Beauv & 25.0 & 8.9 & 66.5 & \\
\hline Pakuay yai grass & Dactyloctenium sp. & 21.3 & 10.4 & 60.7 & \\
\hline Phaek grass & Themeda triandra (Forssk.) & 32.4 & 9.5 & 46.2 & \\
\hline Yung grass & Microstegium ciliatum & 32.4 & 6.2 & 67.3 & \\
\hline Due leaves & Ficus fistulose & 9.3 & 16.9 & 48.5 & \\
\hline Mimosa & Albizia julibrissin & 12.3 & 22.0 & 39.7 & \\
\hline Sweet potato vine & Ipomoea batatas & 3.3 & 15.7 & 32.7 & \\
\hline Todma & Paederia linearis Hook. f. & 1.1 & 12.6 & 51.7 & \\
\hline Wild banana & Musa itinerans var. & 7.1 & 16.2 & 54.4 & \\
\hline Loa grass & Erianthus sp. & 34.4 & 13.1 & 81.5 & {$[14]$} \\
\hline Erythrina leaves & Erythrina variegata Linn & 19.1 & 21.1 & 62.2 & \\
\hline Leucaena leaves & Leucaena leucocephala & 28.0 & 27.6 & 50.1 & \\
\hline Dry cassava leaves & Manihot esculenta (L.) Crantz. & 75.8 & 21.9 & 19.3 & {$[15]$} \\
\hline Fresh cassava leaves & Manihot esculenta (L.) Crantz. & 33.0 & 11.8 & 32.9 & \\
\hline Marsh grass & Hymenachne sp. & 24.3 & - & 74.0 & {$[16]$} \\
\hline Bamyard grass & Echinochloa sp & 26.1 & - & 55.5 & \\
\hline
\end{tabular}

DM, dry matter; $C P$, crude protein; NDF, neutral detergent fiber. 
Table 5. Crop production and residual waste in Laos

\begin{tabular}{cccccc}
\hline \multirow{2}{*}{ Year } & \multicolumn{2}{c}{ Rice } & & \multicolumn{2}{c}{ Cassava } \\
\cline { 2 - 3 } \cline { 5 - 6 } & $\begin{array}{c}\text { Yield }{ }^{1)} \\
\text { (Tonnes/yr) }\end{array}$ & $\begin{array}{c}\text { Rice straw }{ }^{2)} \\
\text { (Tonnes/yr) }\end{array}$ & & $\begin{array}{c}\text { Yield }{ }^{1)} \\
\text { (Tonnes/yr) }\end{array}$ & $\begin{array}{c}\text { Cassava pulp }{ }^{3)} \\
\text { (Tonnes/yr) }\end{array}$ \\
\hline 2005 & $2,568,000$ & $1,412,400$ & & 51,300 & 7,695 \\
2006 & $2,663,700$ & $1,465,035$ & & 174,490 & 26,174 \\
2007 & $2,710,050$ & $1,490,528$ & & 233,420 & 35,013 \\
2008 & $2,969,910$ & $1,633,451$ & & 261,970 & 39,296 \\
2009 & $3,144,800$ & $1,729,640$ & & 152,590 & 22,889 \\
2010 & $3,070,640$ & $1,688,852$ & & 500,090 & 75,014 \\
2011 & $3,065,760$ & $1,686,168$ & & 743,190 & 111,479 \\
2012 & $3,489,210$ & $1,919,066$ & & $1,060,880$ & 159,132 \\
2013 & $3,414,560$ & $1,878,008$ & & $1,254,188$ & 188,128 \\
2014 & $4,002,425$ & $2,201,334$ & & $1,629,805$ & 244,471 \\
2015 & $4,102,000$ & $2,256,100$ & & $2,382,478$ & 357,372 \\
2016 & $4,148,800$ & $2,281,840$ & & $3,095,864$ & 464,380 \\
\hline
\end{tabular}

1) Crop Production in Lao PDR [22].

${ }^{2)}$ The quantity of rice straw produced 8.31 million tons/yr (55\%) from 15.11 million tons/yr of rice production [23].

${ }^{3)}$ Cassava pulp is $15 \%$ of cassava starch production [24].

plantations within Laos with a total registered capital investment of USD 64.8 million covering a concessional land area of 11,428 hectares [20]. The production of cassava increased from 743,170 tons in FY 2010-2011 to 1,513,920 tons in FY 2014-2015 [1]. Currently, there are 5 cassava starch factories with a total planted area of 60,475 ha, and annual production is of the order of 1.6 million tonnes [21]. Cassava pulp is an agro-industrial by-product of the cassava industry and is a potential biomass source for ruminant production because it contains significant amounts of starch suitable as a feed energy source.

Wet brewers' grains are generated form the manufacture of beer. Previous research has shown that the brewers' grains are of high nutritive value, notably for their crude protein, crude fiber and nitrogen free extract content. They have become widely used as protein source in ruminant feeds because the cost of wet brewers' grains in the Laos capital, Vientiane is low at approximately 0.156 US $\$$ per kilogram dry matter $(8,323$ $\mathrm{LAK}=1 \mathrm{USD}$ ).

Disease problems in ruminants: Even though foot and mouth disease (FMD) and haemorrhagic septicaemia (HS) are considered as important constraints on large ruminant health and production in Laos [25,26], some smallholder farmers do not have access to vaccines and some are not concerned about control as almost all farmers has little understanding of and lack funds to improve husbandry. Khounsy [27] reported that FMD virus serotype $\mathrm{O}$ is the dominant cause of FMD outbreaks in Laos during 1998 to 2005. The majority of outbreaks occurred in Vientiane Capital (28\%) and the highest number of outbreaks were reported in cattle (61\%); followed by buffalo (27\%) and pigs (12\%). All type A outbreaks occurred in cattle. Type Asia 1 outbreaks were reported in the central provinces around Vientiane Capital between 1996 and 1998. Moreover, FMD outbreaks were reported in at least 4 of the 8 Northern provinces in Laos in each year from 2009 to 2011 with outbreaks occurring in 2 of the 3 years Xiangkhouang, Sayaboury, and Houaphanh provinces [26]. The estimation of financial losses due to FMD per household was USD 1124, USD 862 and USD 381 in Luang Prabang, Xiangkhouang, and Sayaboury, respectively, being $60 \%, 40 \%$, and $16 \%$ of the household annual income [28]. In spite of livestock vaccination rates increasing nationally between 1999 and 2011, the vaccination rate for cattle in Laos is less than $60 \%$ and is mainly for HS, reflecting the low availability of vaccines and veterinary services in Laos where only $2 \%$ of rural villages have access to a veterinary clinic [26].

It has been reported that farmers treated the FMD infected ruminants by using of traditional medicine such as star-fruit and lime juice, commercial vinegar and boiling tree bark (Ptesocarpus pedatus Pierre) to wash FMD lesions [28]. Additionally, penicillin is used on some affected ruminants, and sick animals are regularly isolated from the healthy animals. In fact, most farmers have been willing to pay up to 0.8 dollars per dose for vaccines $[26,28]$. However, FMD control in Lao PDR requires regional international cooperation, as promoted by the Regional Coordination Unit of The World Organisation for Animal Health (OIE) sub-commission for FMD in southeast Asia (SEAFMD) that has developed a roadmap for disease freedom by vaccination by 2020 [26]. Importantly, vaccination strategies must be complemented with other recommended interventions, including developed animal movement control and quarantine, improved surveillance and reporting, plus public awareness of FMD disease risk.

\section{FUTURE PROSPECTS FOR BEEF PRODUCTION IN LAOS}

Lao PDR's population and income levels continue to increase, and new trade agreements have opened the door for significant growth in the meat industry. The demand for bovine meat in Laos is increasing, generating an opportunity for smallholder farmers particularly in the bigger cities, with the most outstanding production growth in Savannakhet, Vientiane, Champasak, Xiangkhouang, and Sayaboury [6] where fattening of cattle has quickly developed in recent years because bovine meat prices increase of $42 \%$ to $48 \%$ between 2011 and 2013 [29]. Recently, Wagyu cattle farming in Laos has been established with the aim of providing high quality meat in Xiangkhouang Province. However, there are a number of obstacles to address in order for this opportunity to be realized, notably feed quality and availability. In addition, vaccination to prevent common diseases is essential to minimize economic losses.

Since China proposed the Belt and Road Initiative (BRI) in 2013, Laos has been a major partner in cooperation. Sev- 
eral railways are planned or under construction, stretching from Kunming in southwest China, crossing Vietnam, Laos, Cambodia, Myanmar, Thailand, Malaysia, and ending in Singapore, which will connect China closely with all countries in Southeast Asia. Importantly, BRI will turn Laos from a landlocked nation into one which effectively links various countries because the railways will help to facilitate people-to-people exchanges, reduce travel time and costs, and promote agricultural production in Laos.

\section{CONFLICT OF INTEREST}

We certify that there is no conflict of interest with any financial organization regarding the material discussed in the manuscript.

\section{ACKNOWLEDGMENTS}

The authors would like to express our sincere thanks for their research facilities support to: Program in Animal Production Technology, Faculty of Technology, Udon Thani Rajabhat University (UDRU), Thailand; Department of Livestock and Fisheries, Faculty of Agriculture, National University of Laos (NUOL), Lao PDR.

\section{REFERENCES}

1. Committee on Ministry of Planning and Investment, Ministry of Planning and Investment. 8th Five-year National Socioeconomic Development Plan (2016-2020). Vientiane Capital, Lao PDR: Ministry of Planning and Investment; 2016.

2. Okuda Y, Kanii T, Yamamoto Y, et al. Genetic characterization of Laotian native cattle using mtDNA haplotype and loci associated with economical traits, coat color, and a hereditary disorder. J Anim Genet 2017;45:43-8.

3. Live Animal in Lao PDR [Internet]. FAOSTAT; [cited 2017 Jan 8]. Available from: http://www.fao.org/faostat/en/\#data/ QA.

4. Safari J, Mushi DE, Kifaro GC, et al. Seasonal variation in chemical composition of native forages, grazing behaviour and some blood metabolites of small East African goats in a semi-arid area of Tanzania. Anim Feed Sci Technol 2011;164: 62-70.

5. Keba HT, Madakadze IC, Angassa A, Hassen A. Nutritive value of grasses in semi-arid rangelands of Ethiopia: local experience based herbage preference evaluation versus laboratory analysis. Asian-Australas J Anim Sci 2013;26:366-77.

6. Committee on Ministry of Agriculture and Forestry, Ministry of Agriculture and Forestry. Agricultural Statistics Year Book. Vientiane Capital, Lao PDR: Department of Planning; 2016.

7. Committee on Lao Department of Statistics, Ministry of Planning and Investment. Statistical Year Book 2010. Vientiane
Capital, Lao PDR: Department of Statistics; 2011.

8. Committee on Lao Department of Statistics, Ministry of Planning and Investment. Statistical Year Book 2011. Vientiane Capital, Lao PDR: Department of Statistics; 2012.

9. Committee on Lao Department of Statistics, Ministry of Planning and Investment. Statistical Year Book 2012. Vientiane Capital, Lao PDR: Department of Statistics; 2013.

10. Committee on Lao Department of Statistics, Ministry of Planning and Investment. Statistical Year Book 2014. Vientiane Capital, Lao PDR: Department of Statistics; 2015.

11. Committee on Lao Department of Statistics, Ministry of Planning and Investment. Statistical Year Book 2016. Vientiane Capital, Lao PDR: Department of Statistics; 2017.

12. World Bank [Internet]. GNI per capita, Atlas method (current US\$); [cited 2018 April 8]. Available from: https://data.world bank.org/indicator/NY.GNP.PCAP.CD

13. Napasirth V, Maniseng B. The effects of urea-treated rice straw and sugarcane bagasse on voluntary feed intake and growth performance in Lao native cattle. Lao J Agric Forest 2008;16: 98-110.

14. Napasirth V, Sivilay B, Komgmanila D, Inthapanya S. The study of chemical composition and nutritive value of animal feed resource in Northern Lao PDR.: Luangprabang and Sayaboury provinces. Lao J Agric Forest 2008;18:132-48.

15. Napasirth V, Tavanikone C, Sayavong K. Effects of levels of fresh and dried cassava leaves as supplemented feed on feed intake and growth performance in native cattle. Lao J Agric Forest 2010;21:98-106.

16. Napasirth P, Napasirth V, Cai Y. Effect of effective microorganism (EM) and cassava starch on the physical quality and organic acid compositions of native grasses silage in central region of Lao PDR. Khon Kaen Agric J 2014;42(Suppl):29-34.

17. Sundstol F, Said AN, Arnason J. Factors influencing the effect of chemical treatment on the nutritive value of straw. Acta Agric Scandinavian 1979;29:179-90.

18. Napasirth V, Wanapat M, Berg J. Assessment of urea and/or lime treatment on rice straw quality using in vitro gas fermentation technique. J Anim Vet Adv 2012;11:295-9.

19. Wanapat M, Kang S, Hankla N, Phesatcha K. Effect of rice straw treatment on feed intake, rumen fermentation and milk production in lactating dairy cows. Afr J Agric Res 2013; 8:167787.

20. Soukkhamthat T, Wong GY. Technical efficiency analysis of small scale cassava farming in Lao PDR. Asian J Agric Rural Dev 2016;13:1-19.

21. Committee on Department of Agriculture, Ministry of Agriculture. Crop Statistic Year Book. Vientiane Capital, Lao PDR: Department of Agriculture; 2014.

22. Crop Production in Lao PDR [Internet]. FAOSTAT; [cited 2017 Jan 8]. Available from: http://www.fao.org/faostat/en/\#data/ QC

23. Kanokkanjana K, Garivait S. Alternative rice straw manage- 
ment practices to reduce field open burning in Thailand. IJESD 2013;4:119-23.

24. Sriroth K, Piyachomkwan K, Wanlapatit S, Oates CG. Cassava starch technology: the Thai experience. Starch/Stärke 2000;52: 439-49.

25. Rast L, Windsor PA, Khounsy S. Limiting the impacts of foot and mouth disease in large ruminants in northern Lao People's Democratic Republic by vaccination: a case study. Transbound Emerg Dis 2010;57:147-53.

26. Nampanya S, Khounsy S, Young JR, et al. Smallholder large ruminant health and production in Lao PDR: challenges and opportunities for improving domestic and regional. Anim Prod Sci 2016;57:1001-6.
27. Khounsy S, Conlan JV, Gleeson LJ, et al. Foot and mouth disease in the Lao People's Democratic Republic: I. A review of recent outbreaks and lessons from control programmes. Rev Sci Tech 2008;27:839-49.

28. Nampanya S, Khounsy S, Phonvisay A, et al. Financial impact of foot and mouth disease on large ruminant smallholder farmers in the Greater Mekong Subregion. Transbound Emerg Dis 2015;62:555-64.

29. Nampanya S, Khounsy S, Phonvisay A, et al. Improving smallholder food security through investigations of carcass composition and beef marketing of buffalo and cattle in northern Lao PDR. Trop Anim Health Prod 2015;47:681-9. 